\title{
Adenomyoepithelial tumours and myoepithelial carcinomas of the breast - a spectrum of monophasic and biphasic tumours dominated by immature myoepithelial cells Daniela Hungermann ${ }^{1}$, Horst Buerger ${ }^{1}$, Christian Oehlschlegel ${ }^{2}$, Hermann Herbst ${ }^{3}$ and Werner Boecker*1
}

\author{
Address: ${ }^{1}$ Institute of Pathology, Muenster University Hospital, Domagkstrasse 17, 48149 Muenster, Germany, ${ }^{2}$ Institute of Pathology, \\ Kantonsspital St. Gallen, Rorschacher Str. 95, CH-9007 St. Gallen, Switzerland and ${ }^{3}$ Institute of Pathology, Region Süd, Klinikum Neukölln, \\ Rudower Str. 48, 12351 Berlin, Germany \\ Email: Daniela Hungermann - hungerma@uni-muenster.de; Horst Buerger - burgerh@uni-muenster.de; \\ Christian Oehlschlegel - christian.oehlschlegel@kssg.ch; Hermann Herbst - hermann.herbst@vivantes.de; Werner Boecker* - boeckew@uni- \\ muenster.de \\ * Corresponding author
}

Published: 28 July 2005

BMC Cancer 2005, 5:92 doi:10.1 186/147/-2407-5-92

This article is available from: http://www.biomedcentral.com/I47/-2407/5/92

(c) 2005 Hungermann et al; licensee BioMed Central Ltd.

This is an Open Access article distributed under the terms of the Creative Commons Attribution License (http://creativecommons.org/licenses/by/2.0), which permits unrestricted use, distribution, and reproduction in any medium, provided the original work is properly cited.

\begin{abstract}
Background: Adenomyoepithelial tumours and myoepithelial carcinomas of the breast are primarily defined by the presence of neoplastic cells with a myoepithelial immunophenotype. Current classification schemes are based on purely descriptive features and an assessment of individual prognosis is still problematic.

Methods: A series of 27 adenomyoepithelial tumours of the breast was analysed immunohistochemically with antibodies directed against various cytokeratins, p63, smooth muscle alpha-actin (SMA) and vimentin. Additionally, double immunofluorescence and comparative genomic hybridisation (CGH) was performed.

Results: Immunohistochemically, all the tumours showed a constant expression of high molecular weight cytokeratins (Ck) $\mathrm{Ck} 5$ and $\mathrm{Ck}$ I4, p63, SMA and vimentin. With exception of one case diagnosed as myoepithelial carcinoma, all tested tumours expressed low molecular weight cytokeratin $\mathrm{Ck} / 8$ in variable proportions of cells. Even in monophasic tumours lacking obvious glandular differentiation in conventional staining, a number of neoplastic cells still expressed those cytokeratins. Double immunofluorescence revealed tumour cells exclusively staining for $\mathrm{Ck} 5 / \mathrm{Ck} / 4$ in the presence of other cell populations that coexpressed high molecular weight $\mathrm{Ck} 5 / \mathrm{CkI} 4$ as well as either low molecular weight $\mathrm{Ck} 8 / \mathrm{I} 8$ or SMA. Based on morphology, we assigned the series to three categories, benign, borderline and malignant. This classification was supported by a stepwise increase in cytogenetic alterations on $\mathrm{CGH}$.

Conclusion: Adenomyoepithelial tumours comprise a spectrum of neoplasms consisting of an admixture of glandular and myoepithelial differentiation patterns. As a key component SMA-positive cells coexpressing cytokeratins could be identified. Although categorisation of adenomyoepithelial tumours in benign, borderline and malignant was supported by results of $\mathrm{CGH}$, any assessment of prognosis requires to be firmly based on morphological grounds. At present it is not yet clear, if and to what extent proposed Ck5-positive progenitor cells contribute to the immunohistochemical and morphological heterogeneity of these neoplasms of the breast.
\end{abstract}




\section{Background}

Adenomyoepithelial tumours are a widely accepted, yet poorly understood diagnostic entity of breast neoplasms, the definition of which is based on cytological and architectural features. According to the most recent WHO classification, the spectrum of tumours included under this heading ranges from organoid, bi-phasic tumors with a combination of easily recognisable tubular formations and multi-layered spindle-celled myoepithelial elements to monophasic lesions with "mesenchymal" appearance [1-3].

In tumours of monophasic "mesenchymal" appearance, a potentially glandular differentiation can sometimes only be identified by staining for low-molecular-weight cytokeratins (Ck) Ck8/18. Malignant tumours without obvious morphological and immunophenotypic glandular features are currently classified as malignant myoepithelioma or myoepithelial carcinoma. These malignancies are characterized by infiltrating proliferations of atypical spindle cells with high mitotic activity, often displaying a dot-like cytoplasmic expression of smooth muscle $\alpha$-actin (SMA), vimentin and Ck14. Because of this phenotypic heterogeneity, a specific position within the spectrum of proliferative breast lesions has not been assigned to adenomyoepithelial neoplasms, and unequivocal criteria for prognostic assessment have not yet been established $[4,5]$.

We studied a series of 27 adenomyoepithelial tumours by comparative genomic hybridisation (CGH), double immunofluorescence and immunostaining for Ck5, Ck14, Ck8/18 and Ck19, as well as for vimentin, p63, SMA and the proliferation antigen detected by the monoclonal antibody MIB-1. Our data indicates that adenomyoepithelial tumours represent a spectrum of lesions that constantly express $\mathrm{Ck} 5$ and alternately show glandular and myoepithelial elements.

\section{Methods}

\section{Tissue blocks}

Tissue blocks of 27 cases, most of them referral cases, were selected from the files of the Institutes of Pathology of Muenster University Hospital and Kantonsspital St. Gallen. The tissue material had been fixed in neutral buffered formalin and paraffin-embedded according to standard procedures. Diagnoses were based on morphologic criteria using haematoxylin and eosin (H\&E)-stained sections and immunohistology for Ck5 and Ck14, Ck8/18 and smactin. The clinical data, as far as available, is summarised in Table 1. The median age of patients presenting with a benign adenomyoepithelial tumour was 51 years, all patients were female. The median age of the patients with malignant adenomyoepithelial tumours was 53 years. Tumours classified as benign comprised a broad spectrum of histological differentiation ranging from biphasic lesions with well definable tubular structures to monophasic types, whereas almost all malignant tumours displayed a "mesenchymal" appearance. In order to be classified as benign, adenomyoepithelial tumours had to fulfil the following criteria: benign cytomorphology, a mitotic rate of less than $15 \%$, and absence of invasive features. Malignancy was diagnosed when the following criteria were met: a mitotic rate exceeding $15 \%$ and/or malignant cytomorphology and/or invasive growth pattern. Those cases that did not fit either group were regarded as borderline tumours.

\section{Immunohistology}

Paraffin sections of 8 benign, 5 borderline-type and 14 malignant adenomyoepithelial tumours were stained with antibodies (Table 2) using LSAB/ HRP (Ventana Nexes, Ventana Medical Systems, Tuscon, USA) or the LSAB/ AP (DAKO-Autostainer, DAKO Hamburg, Germany) techniques with $\mathrm{DAB}$ or Red as substrates, respectively.

\section{Double immunofluorescence experiments}

After incubation with a first primary monoclonal antibody $(\mathrm{mAb})$ sections were washed and incubated with FITC-conjugated rabbit anti-mouse antibodies (Dianova, Hamburg, Germany; diluted $1: 50$ ). They were then incubated with the second primary mAb that had been biotinylated previously (ARK ${ }^{\mathrm{TM}}$ biotinylating kit; Dako). The biotin label was subsequently visualised with Cy3-conjugated streptavidin (Dianova, $1: 200$ ). SMA was detected using a directly FITC-conjugated antibody. Counterstaining was performed with DAPI (Sigma, $5 \mu \mathrm{g} / \mathrm{ml}$ Tris buffer) for $15 \mathrm{~s}$, and specimens were mounted with Vectashield (Vector Laboratories, Burlingame, USA). Controls were incubated without primary antibody or with mouse IgG. All cases were also stained using conventional enzyme immunolabeling [6].

\section{Microscopy and image processing}

Immunostained slides were examined using a Zeiss Axioplan 2 bright field/fluorescence microscope equipped with appropriate filters. Separate images for DAPI, Cy3, and FITC staining were captured digitally from doublestained specimens into colour-separated components using an AxioCam digital camera (Carl Zeiss, Göttingen, Germany) and AxioVision 2.05 multi-channel image processing (Carl Zeiss Vision GmbH, Hallbergmoos, Germany). The red (for Cy3), blue (for DAPI), and green (for FITC) components were merged and composed for further analysis.

\section{Microdissection and DNA extraction}

Manual microdissection was performed with a minimum of ten serial sections of $10 \mu \mathrm{m}$ thickness cut from the paraffin blocks of all of the benign and malignant 
Table I: Clinical data and results of conventional histology and immunohistology of adenomyoepithelial tumours of the breast.

\begin{tabular}{|c|c|c|c|c|c|c|c|c|c|c|c|c|c|c|c|c|c|c|c|}
\hline Case & age & Diagnosis & Pleomorphism & Necrosis & $\begin{array}{l}\text { Tumour } \\
\text { border }\end{array}$ & CKI4 & Ck19 & Ckl 8 & CDII7 & Vim & P63 & Ck5/6 & S100 & KL-I & SMA & $\begin{array}{l}\text { MIB- } \\
\text { I[\%] }\end{array}$ & ER & PR & $\begin{array}{l}\text { Mitoses/ } \\
\text { I OHPF }\end{array}$ \\
\hline 1 & 42 & benign, biphasic AM/ tubular & 0 & 0 & s & $(+++)$ & $(++)$ & $(++)$ & $(++)$ & $(+)$ & $(+++)$ & $(+++)$ & nd & $(+)$ & $(+++)$ & 2 & $(+)$ & $(+)$ & 0 \\
\hline 2 & 57 & $\begin{array}{l}\text { benign, biphasic AM/ } \\
\text { tubular/ spindle-cellular }\end{array}$ & $(+)$ & 0 & s & s $(+++)$ & $(+++)$ & $(+++)$ & 0 & $(+)$ & nd & $(+++)$ & nd & $(+++)$ & $(+++)$ & 5 & $(+++)$ & $(++)$ & 0 \\
\hline 3 & 50 & $\begin{array}{l}\text { benign, biphasic AM/ } \\
\text { tubular/ lobular }\end{array}$ & $(+)$ & $(+)$ & s & s $\quad(++)$ & (0) & $(+)$ & $(++)$ & $(++)$ & $(+++)$ & $(+++)$ & nd & $(+)$ & $(+)$ & 10 & 0 & 0 & 1 \\
\hline 4 & 75 & benign, biphasic AM/ lobular & $(+)$ & 0 & $s$ & $s \quad(+)$ & $(++)$ & $(++)$ & $(+)$ & $(+)$ & $(+++)$ & $(++)$ & nd & $(+)$ & $(++)$ & 10 & $(+)$ & 0 & 0 \\
\hline 5 & 80 & Benign, biphasic AM/ lobular & $(+)$ & $(+)$ & i & i $\quad(++)$ & $(+)$ & $(+)$ & $(++)$ & nd & $(+++)$ & $(++)$ & $(+)$ & $(+)$ & $(++)$ & 10 & 0 & 0 & 0 \\
\hline 6 & 59 & $\begin{array}{l}\text { benign, biphasic AM/ } \\
\text { tubular/ spindle-cellular }\end{array}$ & $(+)$ & 0 & $s$ & $s$ nd & nd & nd & nd & $(+)$ & nd & $(+++)$ & nd & $(++)$ & $(+++)$ & 15 & $(+++)$ & 0 & I \\
\hline 7 & 65 & $\begin{array}{l}\text { benign, monophasic AM/ } \\
\text { spindle-cellular }\end{array}$ & $(+)$ & 0 & s & s $(+++)$ & 0 & $(+++)$ & 0 & $(+++)$ & nd & $(+++)$ & $(+++)$ & $(+++)$ & $(+++)$ & 1 & 0 & 0 & 0 \\
\hline 8 & 80 & $\begin{array}{l}\text { benign, biphasic AM/ } \\
\text { tubular/ spindle-cellular }\end{array}$ & $(+)$ & 0 & $s$ & s $(+++)$ & $(+++)$ & $(+++)$ & $(+)$ & $(+)$ & nd & $(++)$ & $(++)$ & $(++)$ & $(++)$ & 5 & 0 & 0 & 2 \\
\hline 9 & 64 & $\begin{array}{l}\text { borderline, monophasic AM/ } \\
\text { spindle-cellular }\end{array}$ & $(+)$ & 0 & i & i $(+++)$ & 0 & $(+)$ & $(+)$ & $(+++)$ & $(+++)$ & $(+++)$ & nd & $(+)$ & $(+++)$ & 20 & 0 & 0 & 1 \\
\hline 10 & 78 & $\begin{array}{l}\text { borderline, monophasic AM/ } \\
\text { spindle-cellular }\end{array}$ & $(++)$ & $(+)$ & i & i nd & nd & nd & nd & nd & $(+)$ & $(+++)$ & $(+)$ & $(+)$ & $(+)$ & 30 & 0 & 0 & 1 \\
\hline 11 & 84 & $\begin{array}{l}\text { borderline, monophasic AM/ } \\
\text { spindle-cellular }\end{array}$ & $(+++)$ & 0 & i & $i \quad(+++)$ & 0 & $(+)$ & $(+)$ & $(+++)$ & nd & $(+++)$ & nd & $(+)$ & $(++)$ & 10 & 0 & 0 & 1 \\
\hline 12 & 95 & $\begin{array}{l}\text { borderline, monophasic AM/ } \\
\text { spindle-cellular }\end{array}$ & $(++)$ & 0 & i & i nd & nd & nd & nd & nd & nd & $(+++)$ & $(+)$ & $(+)$ & $(+)$ & 20 & 0 & 0 & 1 \\
\hline 13 & 66 & $\begin{array}{l}\text { borderline, monophasic AM/ } \\
\text { spindle-cellular }\end{array}$ & $(+++)$ & $(+)$ & i & $i \quad(+++)$ & 0 & $(+)$ & $(++)$ & $(+++)$ & $(+++)$ & $(+)$ & nd & 0 & $(+)$ & 10 & 0 & 0 & 0 \\
\hline 14 & 71 & $\begin{array}{l}\text { malignant, monophasic AM/ } \\
\text { spindle-cellular }\end{array}$ & $(+++)$ & $(+)$ & i & i $(+++)$ & 0 & $(+)$ & $(+)$ & $(+++)$ & $(+++)$ & $(++)$ & nd & $(+)$ & $(+)$ & 20 & 0 & 0 & 1 \\
\hline 15 & 68 & $\begin{array}{l}\text { malignant, monophasic AM/ } \\
\text { spindle-cellular }\end{array}$ & $(++)$ & $(+)$ & i & i $(+++)$ & $(++)$ & $(+)$ & $(+)$ & $(+++)$ & $(+++)$ & $(+++)$ & $(+)$ & $(+)$ & $(++)$ & 40 & 0 & 0 & 12 \\
\hline 16 & 93 & malignant Myoepithelioma & $(+++)$ & $(+)$ & $\mathrm{i}$ & i $\quad(+)$ & 0 & 0 & $(++)$ & $(+++)$ & $(+++)$ & $(+++)$ & nd & $(+)$ & $(++)$ & 40 & 0 & 0 & 8 \\
\hline 17 & 85 & $\begin{array}{l}\text { malignant, monophasic AM/ } \\
\text { spindle-cellular }\end{array}$ & $(+++)$ & $(+)$ & $\mathrm{i}$ & $i(+++)$ & 0 & $(+)$ & $(+)$ & $(+++)$ & $(+++)$ & $(+++)$ & nd & $(+)$ & $(++)$ & 20 & 0 & 0 & 1 \\
\hline 18 & 48 & $\begin{array}{l}\text { malignant, monophasic AM/ } \\
\text { spindle-cellular }\end{array}$ & $(++)$ & 0 & $\mathrm{i}$ & i nd & nd & nd & nd & nd & nd & $(+++)$ & nd & $(+)$ & $(+++)$ & 25 & 0 & 0 & 6 \\
\hline 19 & $?$ & $\begin{array}{l}\text { malignant, monophasic AM/ } \\
\text { spindle-cellular }\end{array}$ & $(+++)$ & $(+)$ & $\mathrm{i}$ & $\mathrm{i}(+++)$ & $(+)$ & $(+)$ & 0 & $(++)$ & $(+++)$ & $(+)$ & $(+)$ & $(+)$ & $(+)$ & 50 & 0 & 0 & 25 \\
\hline 20 & 81 & $\begin{array}{l}\text { malignant, monophasic AM/ } \\
\text { spindle-cellular }\end{array}$ & $(+++)$ & $(+)$ & $\mathrm{i}$ & $\mathrm{i}$ nd & nd & nd & nd & nd & nd & $(+++)$ & $(+)$ & $(+)$ & $(+)$ & 20 & 0 & 0 & 2 \\
\hline 21 & 87 & $\begin{array}{l}\text { malignant, monophasic AM/ } \\
\text { spindle-cellular }\end{array}$ & $(+++)$ & $(+)$ & i & i $(+++)$ & 0 & $(+)$ & 0 & $(+++)$ & nd & $(+++)$ & 0 & $(++)$ & $(+++)$ & 50 & 0 & 0 & 10 \\
\hline 22 & 55 & $\begin{array}{l}\text { malignant, monophasic AM/ } \\
\text { spindle-cellular }\end{array}$ & $(+++)$ & $(+)$ & i & i $(+++)$ & $(+++)$ & $(++)$ & $(+)$ & $(+++)$ & nd & $(+++)$ & $(+)$ & $(+)$ & $(+)$ & 80 & 0 & 0 & 22 \\
\hline 23 & 60 & $\begin{array}{l}\text { malignant, biphasic AM/ } \\
\text { spindle-cellular }\end{array}$ & $(+++)$ & $(+++)$ & i & i $(+++)$ & $(+)$ & $(+++)$ & $(++)$ & $(+++)$ & nd & $(+++)$ & $(+++)$ & $(+++)$ & $(+++)$ & 30 & 0 & 0 & 2 \\
\hline 24 & 82 & $\begin{array}{l}\text { malignant, monophasic AM/ } \\
\text { spindle-cellular }\end{array}$ & $(+++)$ & $(+++)$ & i & i $(+++)$ & $(++)$ & $(++)$ & $(++)$ & 0 & nd & $(+)$ & $(+)$ & $(+)$ & $(+++)$ & 75 & 0 & 0 & 12 \\
\hline 25 & 57 & $\begin{array}{l}\text { malignant, monophasic AM/ } \\
\text { spindle-cellular }\end{array}$ & $(++)$ & $(++)$ & i & $i \quad(+++)$ & $(+)$ & $(+)$ & $(+)$ & $(+)$ & nd & $(++)$ & $(+)$ & $(+)$ & $(++)$ & 70 & 0 & 0 & 62 \\
\hline 26 & 45 & $\begin{array}{l}\text { malignant, monophasic AM/ } \\
\text { spindle-cellular }\end{array}$ & $(+++)$ & $(+++)$ & i & i $\quad(+)$ & $(+++)$ & $(++)$ & $(++)$ & $(++)$ & nd & $(++)$ & $(+++)$ & $(+)$ & $(++)$ & 30 & 0 & 0 & 7 \\
\hline 27 & 45 & $\begin{array}{l}\text { malignant, monophasic AM/ } \\
\text { spindle-cellular }\end{array}$ & $(++)$ & $(+++)$ & i & i $\quad(+)$ & $(+++)$ & $(+++)$ & $(++)$ & $(++)$ & nd & $(+)$ & $(+)$ & $(+++)$ & $(++)$ & 60 & 0 & 0 & 11 \\
\hline
\end{tabular}

S = sharply bordered lesions, $\mathrm{i}=$ infiltrative growth pattern

adenomyepithelial tumour specimens. DNA extraction was performed according to standard protocols of proteinase $\mathrm{K}$ digestion $(1 \mathrm{mg} / \mathrm{ml})$ followed by phenol-chloroform extraction.

\section{Comparative genomic hybridisation (CGH)}

As previously described $[7,8]$ fluorescence labeling of 900 ng DNA extracted from microdissected tissue was carried out by standard nick-translation reactions with biotin-16deoxy-uridine-triphosphate (dUTP; Boehringer Mannheim, Mannheim, Germany). 300 ng of reference DNA from a healthy female donor was labeled with digoxigenin-11-dUTP (Boehringer Mannheim).

Regional shifts of the fluorescence ratio profile exceeding the 1.5 threshold were rated as amplifications. Since the target metaphase slides occasionally showed false-positive signals at 1p32-pter, 16p and the entire chromosome 19, those regions were excluded from our analysis.

\section{Results}

\section{Conventional histology}

The adenomyoepithelial tumours analysed in this series displayed great morphological heterogeneity with variable growth patterns and cytological differentiations. All tumours showed at least foci of hyalinisation, sometimes in a basement membrane-like pattern with narrow eosinred bands enmeshing the tumour cells, sometimes with prominent hyalinisation. Eight tumours were diagnosed as benign adenomyoepithelial tumours (Fig. 1, A, B) because they were architecturally inconspicuous and showed neither cytological atypia nor invasive growth. 
Table 2: Antibodies and immunohistological staining procedures

\begin{tabular}{|c|c|c|c|c|c|}
\hline Antigen & Antibody & Source & Dilution & Detection & Pretreatment \\
\hline Vimentin & mAb V9 & DAKO, Glostrup, Denmark & $\mathrm{I}: 1000$ & LSAB/ HRP & Steamer \\
\hline Ki-67 nuclear antigen & mAb MIB-I & DAKO, Glostrup, Denmark & $1: 100$ & LSAB/AP & Steamer \\
\hline broad spectrum Cks & mAb KL-I & Immunotech, Marseille, France & $\mathrm{I}: 50$ & LSAB/ HRP & Steamer \\
\hline Ck5/6 & mAb D5/I6B4 & Zymed, San Francisco, USA & $\mathrm{I}: 50$ & $\mathrm{LSAB} / \mathrm{AP}$ & Steamer \\
\hline Ckl4 & mAb LI002 & dianova GmbH, Hamburg, Germany & $\mathrm{I}: 50$ & $\mathrm{LSAB} / \mathrm{AP}$ & Steamer \\
\hline Ck8/I8 & mAb 5D3 & dianova GmbH, Hamburg, Germany & $\mathrm{I}: 40$ & $\mathrm{LSAB} / \mathrm{AP}$ & Steamer \\
\hline Ckl9 & mAb RCKI08 & DAKO, Glostrup, Denmark & $1: 80$ & $\mathrm{LSAB} / \mathrm{AP}$ & Steamer \\
\hline P63 & $\mathrm{mAb} 4 \mathrm{~A} 4$ & DAKO, Glostrup, Denmark & $1: 100$ & $\mathrm{LSAB} / \mathrm{AP}$ & Steamer \\
\hline Sm- $\alpha-\operatorname{actin}(\mathrm{SMA})$ & mAb IA4 & DAKO, Glostrup, Denmark & I:3000 & $\mathrm{LSAB} / \mathrm{AP}$ & Steamer \\
\hline S-100 protein & Rabbit, polyclonal & DAKO, Glostrup, Denmark & $\mathrm{I}: 1000$ & LSAB/ HRP & - \\
\hline Estrogen receptor & $\mathrm{mAb} 6 \mathrm{FII}$ & Novocastra, Newcastle upon Tyne, UK & $\mathrm{I}: 200$ & LSAB/ AP & Steamer \\
\hline Progesterone receptor & $\mathrm{mAb} 16$ & Novocastra, Newcastle upon Tyne, UK & $\mathrm{I}: 1000$ & LSAB/ AP & Steamer \\
\hline c-Kit & Rabbit, polyclonal & DAKO, Glostrup, Denmark & $1: 100$ & $\mathrm{LSAB} / \mathrm{AP}$ & Steamer \\
\hline
\end{tabular}

mAb, mouse monoclonal antibody

Five of these were biphasic with a combination of tubular structures and multilayered myoepithelial elements, whereas three showed additional areas of pure spindlecell differentiation with bland cytomorphology. In only one of these a "lobular" growth pattern was found. Another two cases were characterized by a lobular growth pattern and one case by pure spindle cell differentiation. The growth fraction (MIB-1 labeling index) did not exceed $15 \%$.

Fourteen adenomyoepithelial tumours were diagnosed as malignant (Fig. 2 A, B) in view of their cytological aspect, an infiltrative or destructive growth pattern and necrosis. The growth fraction exceeded $15 \%$ in all those cases. These malignant adenomyoepithelial tumours often displayed a monophasic pattern consisting of spindleshaped "mesenchymal" cells only. The cells were frequently arranged in a reticular, somewhat more cohesive pattern reminiscent of an abortive glandular differentiation. Other tumours showed an interwoven, storiform pattern and some displayed solid areas with an epitheloid or plasmacytoid aspect. Only one of these malignant tumours contained well-developed tubular structures and was diagnosed as biphasic malignant adenomyoepithelial tumour.

Five lesions could not be included in either of the above groups because they only showed some, but not all the malignant features. Diagnosed as borderline tumours, they displayed a conspicuous cytological variety with a growth fraction ranging from 10 to $30 \%$ and, in some cases, focal necrosis. Irregularities in margin composition were not diagnosed as infiltrative growth. All the tumours of this group were predominantly of spindle-cell type. In six cases $(22 \%)$ of diverse prognostic groups metaplastic squamous cells were found to grow in small nests of kerat- inizing cells. Only one of the twenty-seven tumours which completely lacked glandular differentiation as well as $\mathrm{Ck}$ $8 / 18$ expression was classified as pure myoepithelial carcinoma.

Double immunofluorescence experiments with two biphasic and three monophasic adeno-myoepithelial tumours yielded similar results. We found Ck5-positive tumour cells, glandular (Ck8/18+) and myoepithelial cells (SMA+), as well as cells co-expressing Ck5 and one of the lineage differentiation markers (either $\mathrm{Ck} 5+, \mathrm{Ck} 8 / 18+$ or $\mathrm{Ck} 5+, \mathrm{SMA}+$ ) in all of these lesions (Fig 1, G, H).

\section{Immmunophenotype}

All tumours tested for SMA expressed this antigen. With the exception of one case, all malignant adenomyoepithelial tumours showed reactivity with antibodies directed against vimentin. The high molecular weight cytokeratins Ck5 and Ck14 and SMA were variably expressed in all the tumours of this series. Furthermore, all the tumours tested were positive for $\mathrm{p} 63$ and, with the exception of one malignant neoplasm, all the lesions were at least focally positive for Ck8/18. Reactivity with the Ck19-specific antibody was noted in 5 of $7(71 \%)$ benign, in none of 3 borderline and in 8 of 12 malignant tumours. With the exception of a single case, all tumours showed at least focal reactivity with the antibody KL-1 directed against a broad spectrum of cytokeratins. $78 \%$ of all the tumours tested displayed at least a weak reactivity with an antibody specific for CD117 (c-Kit).

\section{Comparative genomic hybridisation}

In the group of benign adenomyoepithelial lesions, 5 of 7 tumours showed alterations comprising 13 gains and 5 losses of chromosomal regions (mean: 2.6). A total of 9 gains and 10 losses were found in 5 of the borderline 


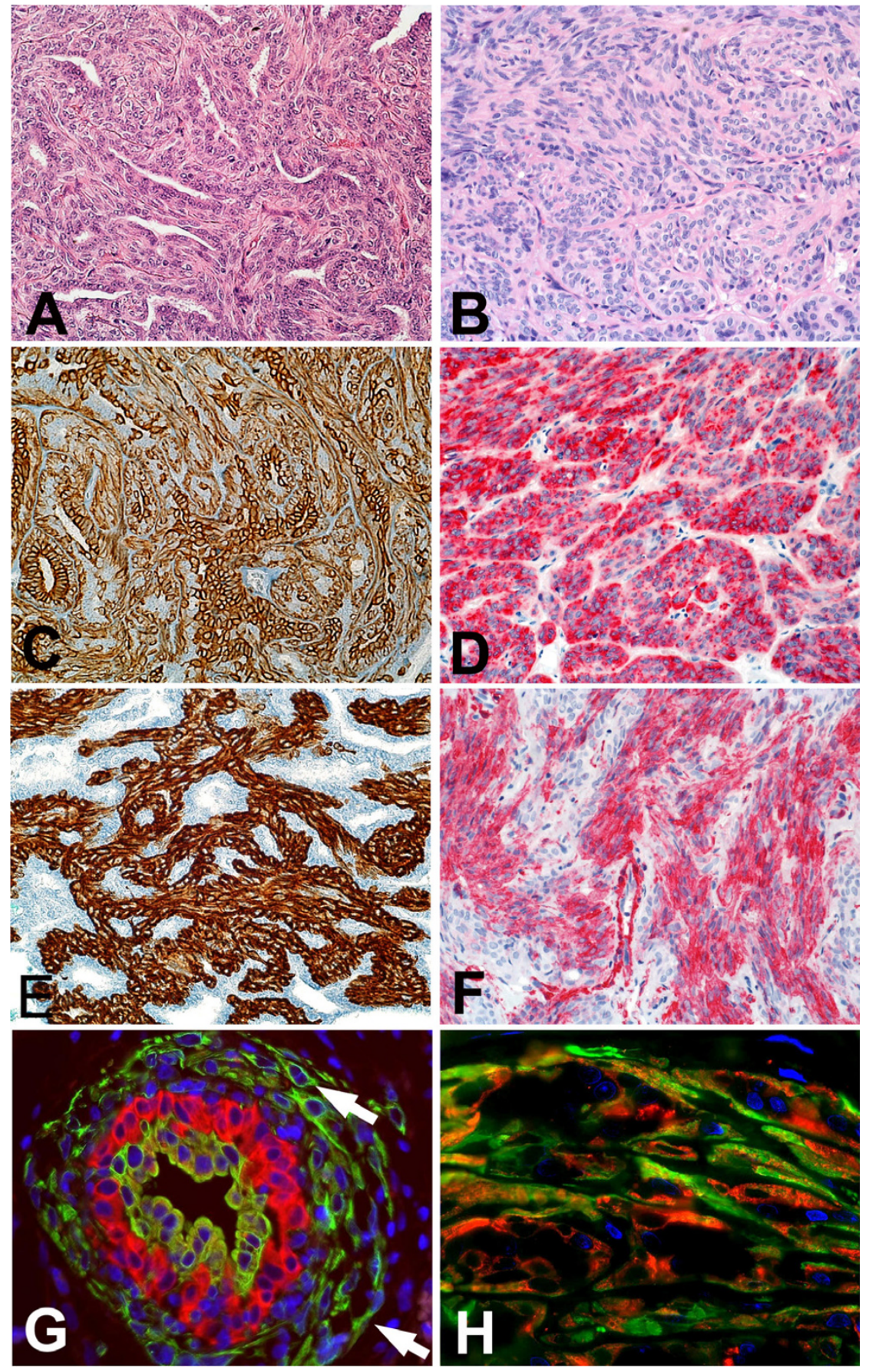

\section{Figure I}

Conventional histology and immunostaining of two benign adenomyoepitheliomas of the breast (A,C,E,G: biphasic; B,D,F: monophasic). A shows a prominent tubular component, whereas in $\mathbf{B}$ a spindle-cell architecture predominates (A, H\&E, magnification $\times 20, D, H \& E$, magnification $\times 20$ ). $\mathbf{C}$ and $\mathbf{D}$ display distribution patterns of basal cytokeratin expression that are tantamount to the proportion of tumour cells (immunostaining for $\mathrm{Ck5/6}$, magnification $\times 20$ ) $\mathbf{E}$ and $\mathbf{F}$ show expression of sm $\alpha$ actin (immunostaining for SMA, magnification $\times 20$ ) with a distribution similar to normal breast tissue in biphasic benign adenomyoepithelioma. G shows double immunofluorescence staining ( $\mathrm{Ck} 5 / 6$ green, $\mathrm{Ck} 8 / \mathrm{l} 8 \mathrm{red}, 40 \times$ ) with prominent abluminal swarming of $\mathrm{Ck5} / 6$-positive cells. The proliferating glandular epithelium consists of differentiated (red signal) and less differentiated (hybrid signal) glandular cells. $\mathbf{H}$ shows double immunofluorescence staining (Ck5 red, SMA green, 63×) of a monophasic, malignant myoepithelial tumour with many cells coexpressing SMA and high molecular weigh Ck5. Note some less differentiated cells that express mainly $\mathrm{Ck} 5$ and some better differentiated cells with a predominance of SMA expression (green signal). 

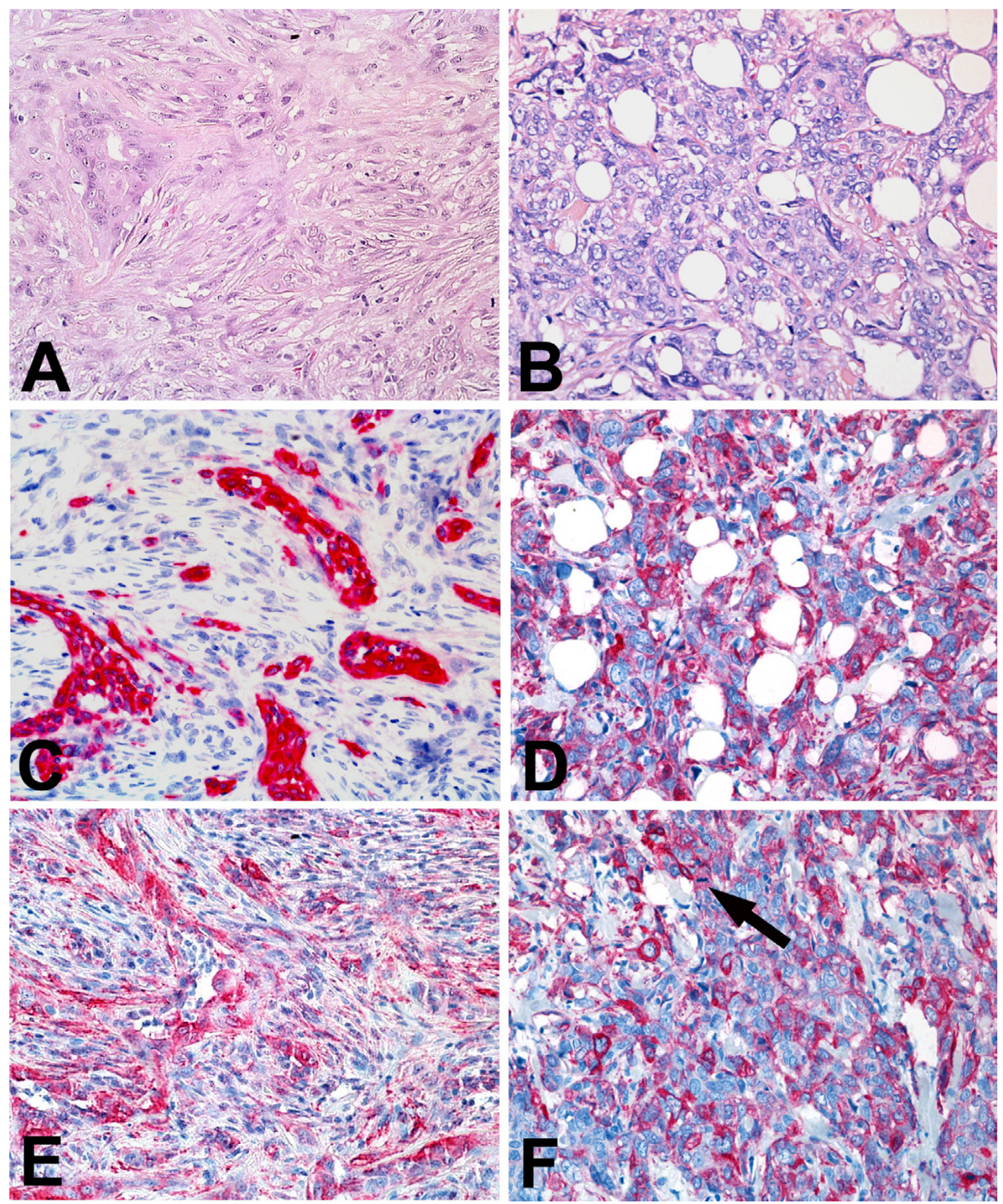

Figure 2

Conventional histology and immunostaining of two malignant adenomyoepitheliomas of the breast. A, C and $\mathbf{E}$ shows a biphasic malignant adenomyoepithelial tumour with distinct tubular formations, whereas $\mathbf{B}, \mathbf{D}$ and $\mathbf{F}$ show a monophasic adenomyoepithelial carcinoma with diffuse infiltration of adipose tissue. $(\mathrm{H} \& \mathbf{E}$, magnification $\times 20 \mathbf{C}$ and $\mathbf{D}$ display distribution patterns of basal cytokeratin expression that are tantamount to the proportion of tumour cells (immunostaining for Ck5/6, magnification $\times 20$ ). $\mathbf{E}$ and $\mathbf{F}$ show expression of SMA in a more irregular distribution compared to normal breast tissue in the malignant biphasic lesion and a rather diffuse pattern in monophasic lesions. A prominent mitotic figure is marked in $F$ (arrow) (magnification $\times 20)$. 

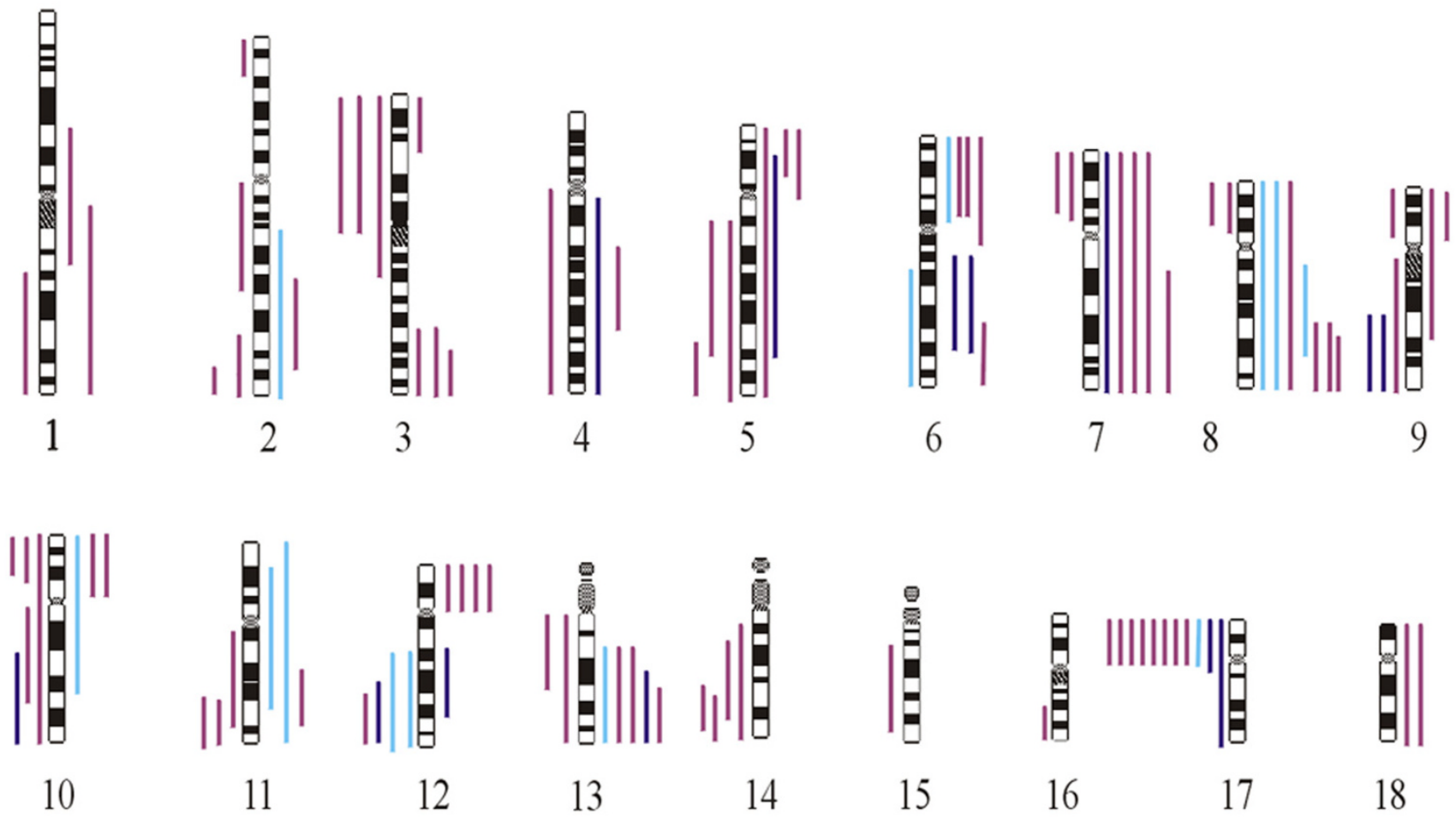

10

11

13

14
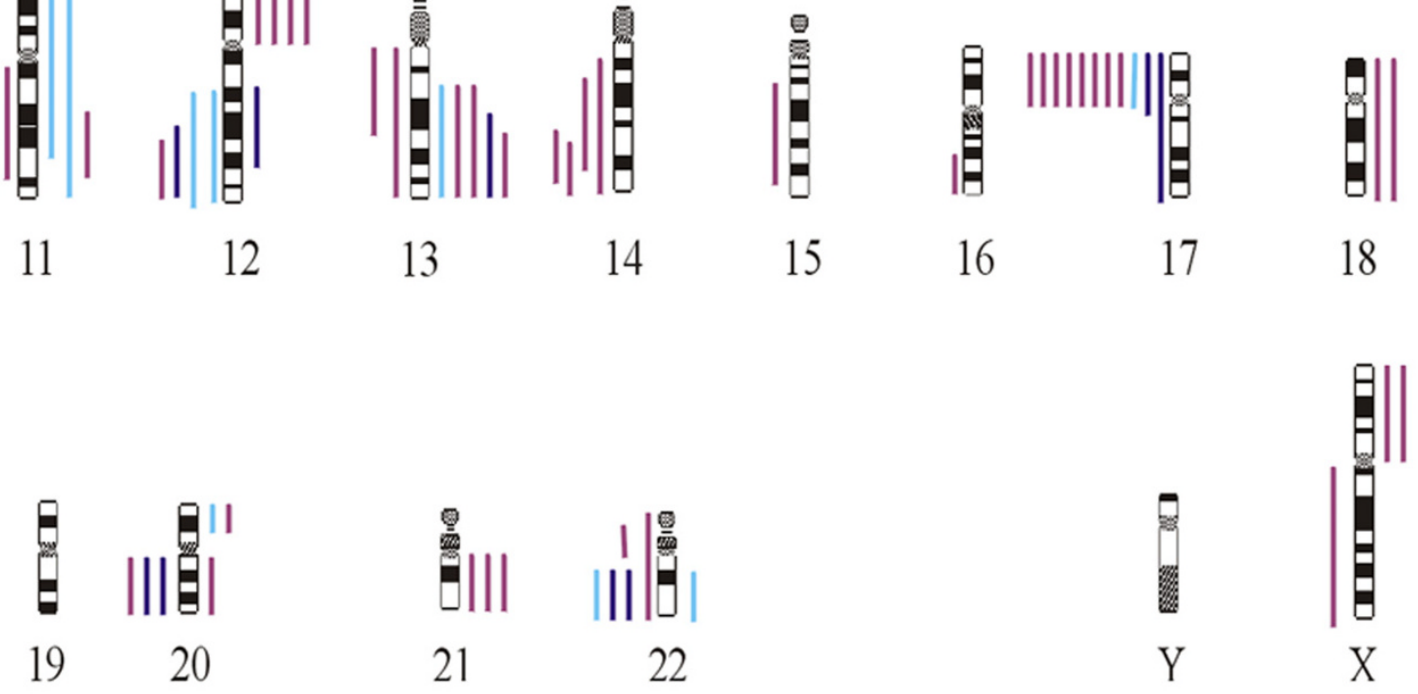

Figure 3

Summary of $\mathrm{CGH}$ profiles of 8 benign adenomyoepitheliomas (light blue), 5 adenomyoepitheliomas of borderline type (dark blue) and I 4 adenomyoepithelial carcinomas (violet). A total of I3I gains and losses are distributed over 22 chromosomes with a preference of chromosomes $8,17 p$ and $13 q$.

tumours, while 3 tumours did not show any alterations (mean: 3.8). In 14 samples of malignant adenomyoepithelial tumours, a total of 94 DNA copy number changes were seen (mean: 6.7), while four malignant adenomyoepithelial tumours did not display any detectable changes (Fig. 3). With a total of 12, the changes on chromosome 8 were most frequent. Losses of $17 \mathrm{p}$ were detected in 6 malignant, 2 borderline and in 1 benign lesion. Less frequent alterations comprised gains of $13 q$ ( 5 cases) and of the short arm of chromosomes 6 and 12, each observed in 4 cases.
Cases no. 8 and 24 were specimens obtained from a lesion diagnosed as benign adenomyoepithelial tumour, which nevertheless recurred two years later as a malignant tumour.

On CGH, the only alteration shared by both tumours was a gain of the long arm of chromosome 8, with amplification on this arm of chromosome 8 in the malignant recurrence. 
We observed a stepwise, although statistically insignificant increase in the number of cytogenetic alterations per case. Their numbers were lowest for benign tumours, but steadily progressed in borderline and malignant adenomyoepithelial tumours. An elevated growth fraction correlated with an increase in the number of cytogenetic alterations $(\mathrm{p}=0.07)$.

\section{Discussion}

Tumours with an adenomyoepithelial differentiation span a broad and morphologically diverse spectrum of neoplasms ranging from patterns with biphasic glandular/myoepithelial architecture to monophasic pure spindle-cell variants. The biology of these rare tumours is poorly understood and their complex nature often gives rise to diagnostic uncertainty, especially when it comes to accurately assessing the prognosis of a given case. The hallmark of these tumours are SMA-positive neoplastic cells co-expressing cytokeratins in variable amounts. Furthermore, all of these tumours share a high proportion of cells that are reactive for basal-type $\mathrm{Ck} 5 / 6$ and $\mathrm{Ck} 14$ and p63 and most, even the monophasic ones, also contain tumour cells with expression of glandular type Ck8/18. This is in glaring contrast to myoepithelial carcinomas which are defined by a complete absence of glandular features. Nevertheless only one (case 16) of the spindle-cell tumours included in this series met the criteria of this category, all other tumours showed at least a small positive reaction with glandular-type cytokeratins. This would indicate that pure myoepithelial carcinomas are extremely rare. This admixture of glandular and myoepithelial components was also described in metaplastic spindle cell carcinoma, "fibromatosis-like" which has to be taken into account in differential diagnosis [9]. In view of our present morphological and immunohistochemical data, some of these tumours might be classified as adenomyoepithelial tumours.

Not unexpectedly, biphasic adenomyoepithelial lesions displayed a Ck8/18 expression that was confined to glandular structures and therefore similar to patterns present in normal breast tissue. Lesions with a monophasic "mesenchymal" appearance, however, displayed a Ck8/18 and Ck19-positive immunophenotype in spindle-cells often arranged in a reticular pattern (Figs 1 and 2. B, D, F). In addition, double immunofluorescence experiments showed co-expression of basal type keratins either in combination with glandular type keratins or SMA as a marker of the myoepithelial lineage. Part of the tumour cells solely expressed $\mathrm{Ck} 5 / 6$. Within the context of a recently published model of differentiation $[6,10,11]$ in normal breast tissue this data would further point towards the existence of Ck5-positive progenitor cells with multi-lineage differentiation potential [12-16]. The potential importance of these presumed progenitor cells has already been shown in mouse tumours with both myoepithelial and glandular differentiation [17].

The assumption that adenomyoepithelial neoplasms are progenitor cell-derived lesions would help to explain the mixed glandular and myoepithelial architecture in the biphasic tumours as well as the bilinear immunophenotype in monophasic lesions. It seems that the tumour cells retain at least some functional remnants of their physiological counterparts. These include basement membrane formation of hemidesmosomes and laminin-binding sites and a strong polarity [18-21]. In the context of this hypothesis, the typical architectural element of adenomyoepithelial tumours, namely the predominant multilayered myoepithelial component with its swarming aspect and enclosed tubules or purely reticular pattern, can be attributed to an immature myoepithelial phenotype and function. Especially the latter may trigger a loss of polarity which leads to an inappropriate sorting of the myoepithelial cells.

From a clinical point of view, no clear criteria for the assessment of patient prognosis have been defined yet. Because these tumours are so rare, available data concerning the prognosis of these tumours is scarce. In accordance with reports in the literature [4,23], we applied criteria commonly used for assessing malignancy of these tumours which unfortunately were shown to be lacking in precision. Mitotic rates of up to 16 mitoses per $10 \mathrm{HPF}$ were reported in lesions categorised as benign, whereas in contrast tumours with less than 3 mitoses per $10 \mathrm{HPF}$ were diagnosed as malignant. Additionally, ill-defined margins and infiltrative growth patterns are observed in tumours of this entity, although it was never conclusively decided whether such features are indicative of a malignant outcome or a remnant of normal behaviour of myoepithelial cells as already documented in vitro [21].

Given this information, we propose a third category of tumours of uncertain prognosis in addition to a benign and a malignant category. The CGH analyses of our series of adenomyoepithelial neoplasms support this idea, because a stepwise increase in the average number of genetic alterations was observed. Growing numbers of genetic alterations are also associated with an increasing growth fraction (>10\%) However, this suggests a continuum in the progression of these tumours and is hardly helpful in the assessment of individual cases. For example, in our series 4 of 14 lesions with features of malignancy did not display any gross genetic alterations. This lack of practical applicability was painfully obvious in the case of an 80-year-old woman (no. 8 and 24) with an incompletely removed lesion described as benign adenomyoepithelial tumour. This apparently benign tumour recurred two years later as an overtly malignant adenom- 
yoepithelioma. The initial tumour showed gains of genetic material in three distinct loci including $8 \mathrm{q}$, whereas the malignant recurrence showed a further amplification on the long arm of chromosome 8 in addition to a loss of genetic material on the long arm of chromosomes 11 and 12. This suggests a clonal progression of changes already present in the initial lesion. Yet, similar to myoepithelial tumours of the salivary glands [24], a specific alteration pattern could not be defined for their counterparts of the breast, a result which is nevertheless in line with most published work in the field.

\section{Conclusion}

Our data suggests the use of a two-tiered terminology according to which adenomyoepithelial tumours are classified as biphasic and monophasic in terms of their deviation from the normal architecture of the myoepithelial-epithelial formation. Furthermore, our data revealed hints for Ck5/6-positive cells as a key component in the histiogenesis of these neoplasms. Nevertheless, any prognostic assessment has to be made on morphological grounds with special attention to proliferative activity.

\section{Competing interests}

The author(s) declare that they have no competing interests.

\section{Authors' contributions}

DH analysed and interpreted the data and drafted the manuscript. $\mathrm{HB}$ made substantial contributions to the interpretation of the data. CO contributed tissue material and patient data as well as critically revising the diagnoses. $\mathrm{HH}$ scrutinised the manuscript, expressed constructive criticism and made most valuable suggestions. WB provided the theoretical framework, supervised the analysis of the data and corrected the manuscript.

\section{Acknowledgements}

The authors thank Ms G. Krull, Ms L. Grothe and Ms U. Neubert for their competent technical support with the $\mathrm{CGH}$ and immunohistochemical analyses. Supported by the Medical Faculty University Münster (grant IMF HUI20II5).

\section{References}

I. Tavassoli FA: Myoepithelial lesions of the breast. In Pathology of the breast Norwalk, Conneticut, USA: Appleton \& Lange; 1992:593-609.

2. Tavassoli FA: Myoepithelial lesions of the breast. Myoepitheliosis, adenomyoepithelioma, and myoepithelial carcinoma. Am J Surg Pathol 1991, 1 5:554-68.

3. Tavassoli FA: Pathology and Genetics of Tumours of the Breast and Female Genital Organs World Health Organisation. IARC; 2003.

4. Bult P, Verwiel JM, Wobbes T, Kooy-Smits MM, Biert J, Holland R: Malignant adenomyoepithelioma of the breast with metastasis in the thyroid gland 12 years after excision of the primary tumor. Case report and review of the literature. Virchows Arch 2000, 436: I58-166.

5. Jones C, Foschini MP, Chaggar R, Lu YJ, Wells D, Shipley JM, Eusebi $\checkmark$, Lakhani SR: Comparative genomic hybridization analysis of myoepithelial carcinoma of the breast. Lab Invest 2000, 80:831-836.

6. Boecker W, Buerger H, Schmitz K, Ellis IA, van Diest PJ, Sinn HP, Geradts J, Diallo R, Poremba C, Herbst H: Usual ductal hyperplasia of the breast is a committed stem (progenitor) cell lesion distinct from atypical ductal hyperplasia and ductal carcinoma in situ. J Pathol 2002, I98:458-467.

7. Kallioniemi A, Kallioniemi OP, Piper J, Tanner M, Stokke T, Chen L, Smith HS, Pinkel D, Gray JW, Waldman FM: Detection and mapping of amplified DNA sequences in breast cancer by comparative genomic hybridization. Proc Natl Acad Sci USA 1994, 91:2156-2160.

8. Buerger H, Otterbach F, Simon R, Schafer KL, Poremba C, Diallo R, Brinkschmidt C, Dockhorn-Dworniczak B, Boecker W: Different genetic pathways in the evolution of invasive breast cancer are associated with distinct morphological subtypes. J Pathol 1999, 1 89:52|-6.

9. Brogi E: Benign and malignant spindle cell lesions of the breast. Semin diagn Pathol 2004, 2 I :57-64.

10. Boecker W, Buerger $\mathrm{H}$ : Evidence of progenitor cells of glandular and myoepithelial cell lineages in the human adult female breast epithelium: a new progenitor (adult stem) cell concept. Cell Prolif 2003, 36:73-84.

II. Korsching E, Packeisen J, Agelopoulos K, Eisenacher M, Voss R, Isola J, van Diest PJ, Brandt B, Boecker W, Buerger H: Cytogenetic alterations and cytokeratin expression patterns in breast cancer: integrating a new model of breast differentiation into cytogenetic pathways of breast carcinogenesis. Lab Invest 2002, 82: I525-I533.

12. Pechoux C, Gudjonsson T, Ronnov-Jessen L, Bissell MJ, Petersen OW: Human mammary luminal epithelial cells contain progenitors to myoepithelial cells. Dev Biol 1999, 206:88-99.

13. Gudjonsson T, Villadsen R, Nielsen HL, Ronnov-Jessen L, Bissell MJ, Petersen OW: Isolation, immortalization, and characterization of a human breast epithelial cell line with stem cell properties. Genes Dev 2002, 16:693-706.

14. Petersen OW, Gudjonsson T, Villadsen R, Bissell MJ, Ronnov-Jessen $\mathrm{L}$ : Epithelial progenitor cell lines as models of normal breast morphogenesis and neoplasia. Cell Prolif 2003, 36:33-44.

15. Dontu G, Al-Hajj M, Abdallah WM, Clarke MF, Wicha MS: Stem cells in normal breast development and breast cancer. Cell Prolif 2003, 36:59-72.

16. Anbazhagan R, Osin PP, Bartkova J, Nathan B, Lane EB, Gusterson BA: The development of epithelial phenotypes in the human fetal and infant breast. J Pathol 1998, I 84:197-206.

17. Li Y, Welm B, Podsypanina K, Huang S, Chamorro M, Zhang X, Rowlands T, Egeblad M, Cowin P, Werb Z, Tan LK, Rosen JM, Varmus HE: Evidence that transgenes encoding components of the Wnt signaling pathway preferentially induce mammary cancers from progenitor cells. Proc Natl Acad Sci U S A 2003, I 00: I 5853-8.

18. Hamperl $\mathrm{H}$, The myothelia (myoepithelial cells): Normal state; regressive changes; hyperplasia; tumors. Curr Top Pathol 1970, 53:161-220.

19. Slade MJ, Coope RC, Gomm JJ, Coombes RC: The human mammary gland basement membrane is integral to the polarity of luminal epithelial cells. Exp Cell Res 1999, 247:267-278.

20. Fu HL, Moss J, Shore I, Slade MJ, Coombes RC: Ultrastructural localization of laminin and type IV collagen in normal human breast. Ultrastruct Pathol 2002, 26:77-80.

2I. Gudjonsson T, Ronnov-Jessen L, Villadsen R, Rank F, Bissell MJ, Petersen OW: Normal and tumor-derived myoepithelial cells differ in their ability to interact with luminal breast epithelial cells for polarity and basement membrane deposition. J Cell Sci 2002, I I 5:39-50.

22. Berdichevsky F, Taylor-Papadimitriou J: Morphological differentiation of hybrids of human mammary epithelial cell lines is dominant and correlates with the pattern of expression of intermediate filaments. Exp Cell Res 1991, I 94:267-274.

23. Damiani S, Riccioni L, Pasquinelli G, Eusebi V: Poorly differentiated myoepithelial cell rich carcinoma of the breast. Histopathology 1997, 30:542-548.

24. Hungermann D, Roeser $K$, Buerger $H$, Jäkel T, Löning $T$, Herbst $H$ : Relative paucity of gross genetic alterations in myoepitheliomas and myoepithelial carcinomas of salivary glands. J Pathol 2002, I 98:487-494. 


\section{Pre-publication history}

The pre-publication history for this paper can be accessed here:

http://www.biomedcentral.com/1471-2407/5/92/prepub

Publish with Bio Med Central and every scientist can read your work free of charge

"BioMed Central will be the most significant development for disseminating the results of biomedical research in our lifetime. " Sir Paul Nurse, Cancer Research UK

Your research papers will be:

- available free of charge to the entire biomedical community

- peer reviewed and published immediately upon acceptance

- cited in PubMed and archived on PubMed Central

- yours - you keep the copyright 